Jay Zysk. Shadow and Substance: Eucharistic Controversy and English Drama Across the Reformation Divide. Notre Dame: University of Notre Dame Press, 2017. Ppxiv, 377. Paperback USD \$45.00. ISBN9780268102302.

\title{
TAMARA ATKIN
}

Queen Mary University of London

In the Gemma anime, or Jewel of the Soul, written by the mysterious twelfthcentury theologian Honorius Augustodunensis, the author likens the confecting priest to a tragedian representing 'the battle of Christ to the people in the theatre of the church through his actions' (pugnam Christi populo Christiano in theatro ecclesiae gestibus suis repraesentat). ${ }^{1}$ Like a tragic actor, the mass-priest represents actions - here Christ's passion, crucifixion, and resurrection - to an audience, his congregation.

The drama described by Honorius is just one illustration of the long historical association between eucharistic rite and theatre, and it shows the importance of liturgical allegory to the history of drama. These issues lie at the heart of Jay Zysk's Shadow and Substance: Eucharistic Controvery and English Drama Across the Reformation Divide, which explores the influence of eucharistic semiotics on medieval and early modern drama. In it, Zysk argues that 'Christ's body is as much a semiotic as a theological construct' (119). While he resists making a claim for the theological origin for literary theory, he shows that throughout Christian history sacramental theology has provided ways for talking and writing about language, sparking debates that have influenced drama written and performed across the Reformation divide. Drawing on an impressive range of theological and dramatic writings, this deeply researched and elegantly written book thereby offers a new model both for the reading of medieval and early modern drama and for thinking about the periodization of literary history.

After an introductory chapter that articulates the book's claims, chapter one offers an account of the rich history of eucharistic debate. Working through four semiotic concepts that have defined medieval and early modern controversy about the eucharist — body and sign; flesh and spirit; literalism and figuralism; and words and deeds - this chapter considers the writings of theologians both before and after the Reformation. Showing the importance of dialogue in these debates, this chapter not only provides a thorough introduction to medieval and early modern writing about the eucharist that is impressive in its own right, but also echoes the structure of the rest of the book, which likewise brings together medieval and early modern texts. 
Each of the remaining five chapters is organized around a key eucharistic topos, and each places two or three plays in conversation in ways that similarly reject a 'trajectory that runs from the medieval to the early modern' (10). Chapter two is about broken bodies, specifically the relationship between wounds and words in medieval biblical plays about the crucifixion and in Shakespeare's tragedy Coriolanus (1608-9). As Zysk notes, these plays 'all but defy comparison', so rather than reading Coriolanus as a type of Christ, he demonstrates the ways in which Shakespeare imaginatively repurposes the semiotics of Christ's wounds to suit the pre-Christian setting of this Roman play (53). The third chapter argues that dramas about royal presence draw on eucharistic imagery and ceremony. Exploring the relationship between Christ's physical, eucharistic, and ecclesial bodies, Zysk shows how the dramatic representation of royal bodies in texts as diverse as Lydgate's royal entry for Henry VI (1432), John Bale's King Johan (ca 1538), and Shakespeare's Macbeth (1606) is informed by evolving Christian thinking about the corpus mysticum. Together, these two chapters showcase Zysk's synchronic approach at its most successful, bringing medieval, Tudor, and professional drama together in ways that challenge accepted readings and shed fresh light on overlooked texts.

Chapter four explores the efficacy of the words and gestures used by priests to make Christ present in the eucharist through readings of the late-medieval morality play Everyman and Christopher Marlowe's Doctor Faustus (A text 1604; $B$ text 1616). Recognizing the unique role of the priesthood to make Christ using language (specifically the words of institution), Zysk argues that where belief in the priest's power to administer the sacraments undergirds Everyman's spiritual journey, as a lay theologian all Faustus can do is 'parody the sacraments he cannot administer and mimic the power over language he cannot wield' (140-1). The fifth and sixth chapters share an interest in the substance of the eucharistic sign. Chapter five explores the staging of relics as a way of focusing questions about eucharistic semiotics in the context of devotional objects. Zysk begins with a reading of the Croxton Play of the Sacrament (after 1461) and, building on recent interpretations of the play's eucharistic host as both a theatrical and sacramental object, he argues that the physical and semiotic violence performed on it recasts it as 'the relic of all holy relics' (166). From here, he moves to a consideration of John Webster's The Duchess of Malfi (1613-14) and Thomas Middleton and William Rowley's The Changeling (1622). Employing spurious relics, these plays dramatize the dangerous instability of all devotional objects by revealing their susceptibility to both religious abuse and semiotic deceit. Conversely, chapter six asks how we can recognize real presence in the absence of outward signs. It pairs the biblical 
dramas of Emmaus with the Tudor interlude Jack Juggler (ca 1553-55) and Shakespeare's The Winter's Tale (1610-11). In their deployment of different forms of disguise, these plays rupture the semiotic relationship between signifier and signified. Only in acts 'of naming and renaming, interpretation and recognition', therefore, can 'the broken bonds between sign and body' be repaired (192).

The book concludes with a short afterword that shows ways in which controversy about eucharistic semiotics extends into the contemporary moment, even affecting the 2011 English translation of the Roman Catholic liturgy. By concluding with these twenty-first-century debates, Zysk illustrates the continued interpenetration of theological and literary discourse in ways that underscore his central premise, namely that eucharistic discourse offered medieval and early modern dramatists ways of thinking about the relationship between words and bodies, language and objects.

Zysk's border-crossing is one of this monograph's strengths, but in places a sharper distinction between medieval and early modern practice might have been fruitful. It may be 'improbable' that professional 'dramatists and audiences studied the formal theological debates over the Eucharist' (4), but many medieval and Tudor playwrights were clerics and very likely steeped in such discussions. More generally, by grouping together all the plays that form the subject of his study as dramas staged in the 'wake' of eucharistic controversy, Zysk risks collapsing the difference between plays about the sacrament and those energized by it, a difference that is absolutely a consequence of changing religious and theatrical circumstance (1). I make this point not as a criticism, but to note the challenges involved in all trans-historical work. That Shadow and Substance so successfully bridges the medieval and early modern is therefore a testament to Zysk's particular brand of scholarship and indicates the wide-reach of this ambitious and stimulating book.

\section{Notes}

1 Jacques-Paul Migne, ed., Patrologiae cursus completus: series Latina, 221 vols in 222 (Paris: Migne, 1844[-64]), 172 (1885), col. 570a, translation my own. 
